\title{
Meta-analysis of human cancer microarrays reveals GATA3 is integral to the estrogen receptor alpha pathway Brian J Wilson and Vincent Giguère*
}

Address: Molecular Oncology Group, Room H5-45, McGill University Health Centre, 687 Pine Avenue West, Montréal, Québec, H3A 1A1, Canada

Email: Brian J Wilson - brian.wilson2@mcgill.ca; Vincent Giguère* - vincent.giguere@mcgill.ca

* Corresponding author

Published: 4 June 2008

Molecular Cancer 2008, 7:49 doi:10.1/86/1476-4598-7-49
Received: 28 November 2007

Accepted: 4 June 2008

This article is available from: http://www.molecular-cancer.com/content/7/1/49

(c) 2008 Wilson and Giguère; licensee BioMed Central Ltd.

This is an Open Access article distributed under the terms of the Creative Commons Attribution License (http://creativecommons.org/licenses/by/2.0), which permits unrestricted use, distribution, and reproduction in any medium, provided the original work is properly cited.

\begin{abstract}
Background: The transcription factor GATA3 has recently been shown to be necessary for mammary gland morphogenesis and luminal cell differentiation. There is also an increasing body of data linking GATA3 to the estrogen receptor $\alpha(E R \alpha)$ pathway. Among these it was shown that GATA3 associates with the promoter of the $E R \alpha$ gene and $E R \alpha$ can reciprocally associate with the GATA3 gene. GATA3 has also been directly implicated in a differentiated phenotype in mouse models of mammary tumourigenesis. The purpose of our study was to compare coexpressed genes, by meta-analysis, of GATA3 and relate these to a similar analysis for ER $\alpha$ to determine the depth of overlap.
\end{abstract}

Results: We have used a newly described method of meta-analysis of multiple cancer studies within the Oncomine database, focusing here predominantly upon breast cancer studies. We demonstrate that ER $\alpha$ and GATA3 reciprocally have the highest overlap with one another. Furthermore, we show that when both coexpression meta-analysis lists for ER $\alpha$ and GATA3 are compared there is a significant overlap between both and, like ER $\alpha$, GATA3 coexpresses with ER $\alpha$ pathway partners such as PS2 (TFFI), TFF3, FOXAI, BCL2, ERBB4, XBPI, NRIPI, IL6ST, keratin I8(KRTI8) and cyclin DI (CCNDI). Moreover, as these data are derived from human tumour samples this adds credence to previous cell-culture or murine based studies.

Conclusion: GATA3 is hypothesized to be integral to the ER $\alpha$ pathway given the following: (I) The large overlap of coexpressed genes as seen by meta-analysis, between GATA3 and ER $\alpha$, (2) The highest coexpressing gene for GATA3 was ER $\alpha$ and vice-versa, (3) GATA3, like ER $\alpha$, coexpresses with many well-known ER $\alpha$ pathway partners such as $\mathrm{pS} 2$.

\section{Background}

While GATA3 has most intensively been studied in the immune system [1] GATA3 is also expressed in other biological environments such as the human endometrium epithelial cells, where levels are regulated in a cyclic manner [2]. GATA3 levels are also considered a good prognostic biomarker in breast tumours. Specifically, in the luminal A subtype of breast cancer GATA3 has both a favorable prognostic outcome, and the highest ER $\alpha$ and GATA3 expression of all breast tumours [3]. Consistent with this, basal-like tumours have the lowest GATA3 expression and the worst prognosis. GATA3 has also been shown in murine models to be essential to the development and maintenance of mammary luminal cells $[4,5]$. There is also tentative data showing that different poly- 
morphisms of the GATA3 gene may associate with differential susceptibility to breast cancer [6].

GATA3 levels have previously been correlated with expression of ER $\alpha$ [7] and both were shown to reciprocally regulate one another at the transcriptional level in a cellculture based system in a cross-regulatory loop [8]. Furthermore, in a meta-analysis of ER $\alpha 10$ genes were proposed as classifier of ER $\alpha$ positive breast tumours, listing GATA3 as one of these [9]. A study has also compared microarray experiments between estradiol-induced genes from MCF-7 cells, and transfected GATA3-induced genes from 293T cells to assess common upregulated genes [10].

In an elegant series of experiments utilizing MMTV-PyMT (polyoma middle T antigen) mice it was first shown that GATA3 expression was downregulated with the transition from adenoma to carcinoma in mammary tumours, and the expression was lost in lung metastases. Infection of the MMTV-PyMT carcinomas with GATA3 upregulated markers of differentiation and resulted in a dramatic 27 -fold reduction in lung metasases [11]. Further crossing of these mice with an inducible cre-WAP (whey acidic protein specific to luminal mammary epithelial cells) driven knockout of GATA3, resulted in loss of markers of terminal differentiation, detachment from the basal membrane and apoptosis. This is consistent with the requirement of GATA3 in differentiated tumours.

As described in a recent study known pathway partners have been shown to yield a similar 'meta-analysis coexpression signature' i.e. having a significant overlap of coexpressed genes can link proteins to the same pathways [12]. Thus performing independent meta-analyses for ER $\alpha$ and GATA3 (putative pathway partners), then comparing the results for overlapping genes would yield a highly significant number of genes if these transcription factors were in the same pathway. We report here not only that these meta-analyses have a high degree of overlap, but that genes identified are consistent with previous reports of the ER $\alpha$ pathway regulation. Additionally we show this correlation with previously identified ER $\alpha$ target genes by combining our meta-analysis data with both RT-PCR and genome-wide location analysis from other studies. These data not only confirm GATA3 as being a key player in the ER $\alpha$ pathway, but also give fresh insights into the pathway itself.

\section{Methods}

\section{Meta-analysis}

The following procedure was undertaken for independent meta-analyses of GATA3 or ER $\alpha$ : a co-expression gene search was performed within Oncomine [13]. Twenty-one studies were chosen for analysis, most of which were breast cancer studies. The top 400 coexpressed genes were extracted and filtered to give one representative gene per study (removing duplicates and ESTs). These filtered genelists were then compared for repeating coexpressed genes over multiple studies. The frequency cutoff was 3 studies (14\% of 21 studies). This generated a meta-analysis list for ER $\alpha$ or GATA3, which were then compared for overlap. As the overlap was high the stringency was increased to 4 studies (19\%), the data of which is used for Table 1. Gene names were obtained using Genecards [14].

\section{Reporter gene assays}

MCF-7 Cells were grown in DMEM (minus phenol-red) with $10 \%$ charcoal-stripped FBS. SKBR3 were grown in DMEM with $10 \%$ FBS. MUC1 $(-881$ to +13$)$ was cloned as a KpnI/Xhol fragment, and KRT18 (-2961 to +96) was cloned as a KpnI/BglII fragment. Both were generated by high-fidelity PCR from human genomic DNA (Roche), and were ligated into pGL4.20 (Promega). pS2 reporter has previously been described [15]. Luciferase reporter gene assays were performed using standard protocols. Here 200-400 ng reporter were transfected with $200 \mathrm{ng}$ pcDNA3 or pcDNA3-GATA3, and 3U/well of $\beta$-galactosidase protein (Sigma) as transfection efficiency control. Ten nM Tamoxifen (Sigma) was incubated for $14 \mathrm{~h}$ prior to cell assay.

\section{Results and Discussion}

Using the Oncomine ${ }^{\mathrm{TM}}$ integrated cancer profiling database GATA3 and ER $\alpha$ were searched for coexpressing genes [13]. Coexpression data from 21 multi-array studies was extracted and analysed, separately for ER $\alpha$ and GATA3. While these studies varied in cancer-types, the overwhelming majority extracted for analysis were breastcancer based [Additional file 1 and 2]. The frequency of coexpressing genes over the 21 studies was determined and the cutoff set to 3 studies or more ( 3 studies $=14 \%$ frequency overlap - [see Additional file 1 and 2]). Next, to ascertain the extent GATA3 may play a role in ER $\alpha$ pathways the frequency coexpression lists were compared for overlap. Interestingly, there was an extensive overlap between both GATA3 and ER $\alpha$ lists at the cutoff of 3 studies (Figure 1A). Increasing the cutoff to 4 or more studies (almost one-fifth of the studies) did not change the relative overlap with respect to total gene numbers, with $43 \%$ of the number of ER $\alpha$ coexpressed genes, and $56 \%$ of GATA3 coexpressed genes represented in the overlap (Figure 1B). The overlap data with the frequency cutoff of 4 studies is shown in Table 1.

Every technique has its caveats, and the limitation here is that we are assessing the common genes that are consistently coexpressed with ER $\alpha$ and GATA3 over many different human cancer studies. This implies that coexpressed genes are in the same pathways as GATA3 and ER $\alpha$. However, the meta-analyses can only infer association within 
Table I: Overlapping meta-analyses of GATA3 and ER $\alpha$ at cutoff of 4 studies (19\%)

\begin{tabular}{|c|c|c|c|}
\hline \multicolumn{4}{|c|}{ Overlap of ER $\alpha$ and GATA3 (4 or more studies) } \\
\hline \multicolumn{4}{|c|}{ ER $\alpha=257$, GATA $3=194$, OVERLAP $=108$} \\
\hline & $\mathbf{E R} \alpha$ & GATA3 & \\
\hline GATA3 & $48 \%$ & $100 \%$ & GATA binding protein 3 \\
\hline ESRI & $100 \%$ & $67 \%$ & estrogen receptor I (estrogen receptor alpha) \\
\hline XBPI & $38 \%$ & $52 \%$ & X-box binding protein I \\
\hline FOXAI & $33 \%$ & $52 \%$ & forkhead box Al \\
\hline $\mathrm{FOXCl}$ & $19 \%$ & $24 \%$ & forkhead box $\mathrm{Cl}$ \\
\hline TFFI & $33 \%$ & $52 \%$ & trefoil factor I (breast cancer, estrogen-inducible sequence expressed in) [pS2] \\
\hline TFF3 & $38 \%$ & $67 \%$ & trefoil factor 3 (intestinal) \\
\hline NRIPI & $19 \%$ & $19 \%$ & nuclear receptor interacting protein I (RIPI40) \\
\hline $\mathrm{BCL} 2$ & $43 \%$ & $67 \%$ & B-cell CLL/lymphoma 2 \\
\hline ACADSB & $38 \%$ & $48 \%$ & acyl-Coenzyme A dehydrogenase, short/branched chain \\
\hline LAF4 & $43 \%$ & $38 \%$ & lymphoid nuclear protein related to AF4 \\
\hline $\mathrm{coX} 6 \mathrm{C}$ & $38 \%$ & $33 \%$ & cytochrome c oxidase subunit Vlc \\
\hline FBPI & $38 \%$ & $33 \%$ & fructose-I,6-bisphosphatase I \\
\hline IGFIR & $38 \%$ & $33 \%$ & insulin-like growth factor I receptor \\
\hline IRSI & $33 \%$ & $33 \%$ & insulin receptor substrate I \\
\hline CELSR2 & $38 \%$ & $38 \%$ & cadherin, EGF LAG seven-pass G-type receptor 2 (flamingo homolog, Drosophila) \\
\hline LRBA & $38 \%$ & $38 \%$ & LPS-responsive vesicle trafficking, beach and anchor containing \\
\hline NATI & $33 \%$ & $\mathbf{5 7 \%}$ & $\mathrm{N}$-acetyltransferase I (arylamine $\mathrm{N}$-acetyltransferase) \\
\hline SCNNIA & $38 \%$ & $57 \%$ & sodium channel, nonvoltage-gated I alpha \\
\hline DNAJCI 2 & $33 \%$ & $48 \%$ & DnaJ (Hsp40) homolog, subfamily $\mathrm{C}$, member 12 \\
\hline RAB3I & $38 \%$ & $19 \%$ & RAB3I, member RAS oncogene family \\
\hline RABEPI & $33 \%$ & $43 \%$ & rabaptin, RAB GTPase binding effector protein I \\
\hline SELENBPI & $33 \%$ & $33 \%$ & selenium binding protein I \\
\hline FAAH & $38 \%$ & $33 \%$ & fatty acid amide hydrolase \\
\hline TNFSFIO & $38 \%$ & $33 \%$ & tumor necrosis factor (ligand) superfamily, member 10 \\
\hline SLC22A 8 & $33 \%$ & $24 \%$ & solute carrier family 22 (organic cation transporter), member I \\
\hline SLC39A6 & $38 \%$ & $\mathbf{5 7 \%}$ & solute carrier family 39 (zinc transporter), member 6 (Estrogen regulated protein LIV-I) \\
\hline SLC40AI & $33 \%$ & $19 \%$ & solute carrier family 40 (iron-regulated transporter), member I \\
\hline SLC9A3RI & $19 \%$ & $43 \%$ & solute carrier family 9 (sodium/hydrogen exchanger), isoform 3 regulator I \\
\hline $\mathrm{SIAH} 2$ & $33 \%$ & $33 \%$ & seven in absentia homolog 2 (Drosophila) \\
\hline SERPINA3 & $38 \%$ & $24 \%$ & serpin peptidase inhibitor, clade A (alpha-I antiproteinase, antitrypsin), member 3 \\
\hline SERPINA5 & $33 \%$ & $19 \%$ & serine (or cysteine) proteinase inhibitor, clade A (alpha-I antiproteinase, antitrypsin), 5 \\
\hline SERPINA6 & $19 \%$ & $24 \%$ & serine (or cysteine) proteinase inhibitor, clade A (alpha-I antiproteinase, antitrypsin), 6 \\
\hline ERBB3 & $33 \%$ & $19 \%$ & v-erb-b2 erythroblastic leukemia viral oncogene homolog 3 (avian) \\
\hline ERBB4 & $19 \%$ & $48 \%$ & v-erb-a erythroblastic leukemia viral oncogene homolog 4 (avian) \\
\hline IL6ST & $24 \%$ & $38 \%$ & interleukin 6 signal transducer (gP I30, oncostatin M receptor) \\
\hline KIAA0040 & $24 \%$ & $24 \%$ & KIAA0040 protein \\
\hline KIAA0303 & $33 \%$ & $43 \%$ & Similar to Mouse serine/threonine protein kinase MAST205 \\
\hline KIAA0882 & $19 \%$ & $19 \%$ & KIAA0882 protein \\
\hline ITPR I & $24 \%$ & $33 \%$ & inositol I,4,5-triphosphate receptor, type I \\
\hline INPP4B & $24 \%$ & $43 \%$ & inositol polyphosphate-4-phosphatase, type II, $105 \mathrm{kDa}$ \\
\hline JMJD2B & $24 \%$ & $48 \%$ & jumonji domain containing $2 \mathrm{~B}$ \\
\hline CI0orfl16 & $24 \%$ & $52 \%$ & chromosome 10 open reading frame 116 \\
\hline ANXA9 & $19 \%$ & $43 \%$ & annexin $\mathrm{A} 9$ \\
\hline AR & $19 \%$ & $33 \%$ & androgen receptor (dihydrotestosterone receptor; Kennedy disease) \\
\hline CCNDI & $19 \%$ & $48 \%$ & cyclin DI (PRADI: parathyroid adenomatosis I) \\
\hline CCNG2 & $19 \%$ & $24 \%$ & cyclin G2 \\
\hline CAI2 & $19 \%$ & $38 \%$ & carbonic anhydrase XII \\
\hline CACNAID & $19 \%$ & $33 \%$ & calcium channel, voltage-dependent, $L$ type, alpha ID subunit \\
\hline CACNA2D2 & $19 \%$ & $43 \%$ & calcium channel, voltage-dependent, alpha $2 /$ delta subunit 2 \\
\hline DNALII & $24 \%$ & $43 \%$ & dynein, axonemal, light intermediate polypeptide I \\
\hline AGR2 & $19 \%$ & $33 \%$ & anterior gradient 2 homolog (Xenepus laevis) \\
\hline GFRAI & $33 \%$ & $48 \%$ & GDNF family receptor alpha I \\
\hline HPN & $19 \%$ & $43 \%$ & hepsin (transmembrane protease, serine I) \\
\hline GREBI & $19 \%$ & $38 \%$ & GREBI protein \\
\hline MAPT & $19 \%$ & $38 \%$ & microtubule-associated protein tau \\
\hline MLPH & $24 \%$ & $33 \%$ & melanophilin \\
\hline
\end{tabular}


Table I: Overlapping meta-analyses of GATA3 and ER $\alpha$ at cutoff of 4 studies (19\%) (Continued)

\begin{tabular}{|c|c|c|c|}
\hline KRTI8 & $24 \%$ & $33 \%$ & keratin 18 \\
\hline PTPRT & $24 \%$ & $48 \%$ & protein tyrosine phosphatase, receptor type, $T$ \\
\hline STC2 & $24 \%$ & $33 \%$ & stanniocalcin 2 \\
\hline SCUBE2 & $33 \%$ & $24 \%$ & CEGPI protein \\
\hline PTGER3 & $33 \%$ & $24 \%$ & prostaglandin E receptor 3 (subtype EP3) \\
\hline PDCD4 & $33 \%$ & $24 \%$ & programmed cell death 4 (neoplastic transformation inhibitor) \\
\hline $\mathrm{MUCl}$ & $33 \%$ & $29 \%$ & mucin I, transmembrane \\
\hline NPYIR & $33 \%$ & $29 \%$ & neuropeptide $Y$ receptor $Y I$ \\
\hline FLJ20366 & $38 \%$ & $24 \%$ & hypothetical protein FLJ20366 \\
\hline TLE3 & $33 \%$ & $29 \%$ & transducin-like enhancer of split 3 (E(sp I) homolog, Drosophila) \\
\hline I3CDNA73 & $24 \%$ & $29 \%$ & hypothetical protein $\mathrm{CG} 003$ \\
\hline AGTRI & $24 \%$ & $29 \%$ & Angiotensin II receptor, type I \\
\hline ASAHI & $24 \%$ & $29 \%$ & $\mathrm{~N}$-acylsphingosine amidohydrolase (acid ceramidase) I \\
\hline $\mathrm{BF}$ & $24 \%$ & $24 \%$ & B-factor, properdin \\
\hline ENPPI & $24 \%$ & $29 \%$ & ectonucleotide pyrophosphatase/phosphodiesterase I \\
\hline QDPR & $24 \%$ & $29 \%$ & quinoid dihydropteridine reductase \\
\hline C9orfl16 & $19 \%$ & $29 \%$ & chromosome 9 open reading frame 116 \\
\hline CYFIP2 & $19 \%$ & $29 \%$ & cytoplasmic FMRI interacting protein 2 \\
\hline GRIA2 & $19 \%$ & $29 \%$ & glutamate receptor, ionotropic, AMPA 2 \\
\hline GSTM3 & $19 \%$ & $29 \%$ & Glutathione S-transferase M3 (brain) \\
\hline $\mathrm{ACO} 2$ & $19 \%$ & $29 \%$ & acyl-Coenzyme $A$ oxidase 2 , branched chain \\
\hline LRIGI & $19 \%$ & $29 \%$ & leucine-rich repeats and immunoglobulin-like domains I \\
\hline PLAT & $19 \%$ & $29 \%$ & plasminogen activator, tissue \\
\hline MAGED2 & $19 \%$ & $29 \%$ & Melanoma antigen family $D, 2$ \\
\hline THRAP2 & $19 \%$ & $29 \%$ & thyroid hormone receptor associated protein 2 \\
\hline MSX2 & $24 \%$ & $24 \%$ & msh homeo box homolog 2 (Drosophila) \\
\hline UGCG & $24 \%$ & $24 \%$ & UDP-glucose ceramide glucosyltransferase \\
\hline ALCAM & $19 \%$ & $24 \%$ & activated leukocyte cell adhesion molecule \\
\hline ALDH4AI & $19 \%$ & $24 \%$ & aldehyde dehydrogenase 4 family, member Al \\
\hline $\mathrm{ABCA} 3$ & $24 \%$ & $19 \%$ & ATP-binding cassette, sub-family $A(A B C I)$, member 3 \\
\hline LOC51760 & $19 \%$ & $24 \%$ & $\mathrm{~B} / \mathrm{K}$ protein \\
\hline PRSS23 & $19 \%$ & $24 \%$ & protease, serine, 23 \\
\hline $\mathrm{RHOH}$ & $24 \%$ & $19 \%$ & ras homolog gene family, member $\mathrm{H}$ \\
\hline TFAP2B & $19 \%$ & $24 \%$ & transcription factor AP-2 beta (activating enhancer binding protein 2 beta) \\
\hline WFDC2 & $24 \%$ & $19 \%$ & WAP four-disulfide core domain 2 \\
\hline ANGPTLI & $19 \%$ & $19 \%$ & angiopoietin-like I \\
\hline BCASI & $19 \%$ & $19 \%$ & breast carcinoma amplified sequence I \\
\hline CYP2B6 & $19 \%$ & $19 \%$ & cytochrome P450, subfamily IIB (phenobarbital-inducible), polypeptide 6 \\
\hline EML2 & $19 \%$ & $19 \%$ & echinoderm microtubule associated protein like 2 \\
\hline FLNB & $19 \%$ & $19 \%$ & filamin B, beta (actin binding protein 278 ) \\
\hline GPRI60 & $19 \%$ & $19 \%$ & $\mathrm{G}$ protein-coupled receptor 160 \\
\hline LU & $19 \%$ & $19 \%$ & Lutheran blood group (Auberger b antigen included) \\
\hline MRPS30 & $19 \%$ & $19 \%$ & mitochondrial ribosomal protein $\mathrm{S} 30$ \\
\hline PTE2B & $19 \%$ & $19 \%$ & peroxisomal acyl-CoA thioesterase $2 \mathrm{~B}$ \\
\hline RERG & $19 \%$ & $19 \%$ & RAS-like, estrogen-regulated, growth inhibitor \\
\hline RNASE4 & $19 \%$ & $19 \%$ & ribonuclease, RNase A family, 4 \\
\hline RNFIIO & $19 \%$ & $19 \%$ & polycomb group ring finger 2 (MEL-18) \\
\hline SEMA3C & $19 \%$ & $19 \%$ & sema domain, immunoglobulin domain $(\mathrm{lg})$, short basic domain, (semaphorin) $3 \mathrm{C}$ \\
\hline SULT2BI & $19 \%$ & $19 \%$ & sulfotransferase family, cytosolic, 2B, member I \\
\hline TPBG & $19 \%$ & $19 \%$ & trophoblast glycoprotein \\
\hline TPD52 & $19 \%$ & $19 \%$ & tumor protein D52 \\
\hline KALI & $19 \%$ & $19 \%$ & Kallmann syndrome I sequence \\
\hline
\end{tabular}

After individual Oncomine meta-analysis of 21 studies both lists of coexpressing genes, for GATA3 and ER $\alpha$ were compared for overlap. Overlap greater than $30 \%$ frequency ( 7 studies) is shown in bold. Overlap list is arranged by percent frequency.

the same pathways, and pathway coexpression at the RNA level might not necessarily translate into protein level. Nevertheless, our data are strongly supported by previous knowledge of the ER $\alpha$ pathway.
A recent study identified 51 genes significantly upregulated in ER $\alpha$ positive breast tumours, using a real-time PCR based approach [16]. Attesting to the stringency of the meta-analysis approach used here 32 of theses genes were found to overlap with the ER $\alpha$ coexpression list, while an identical number also overlapped with GATA3 
A.

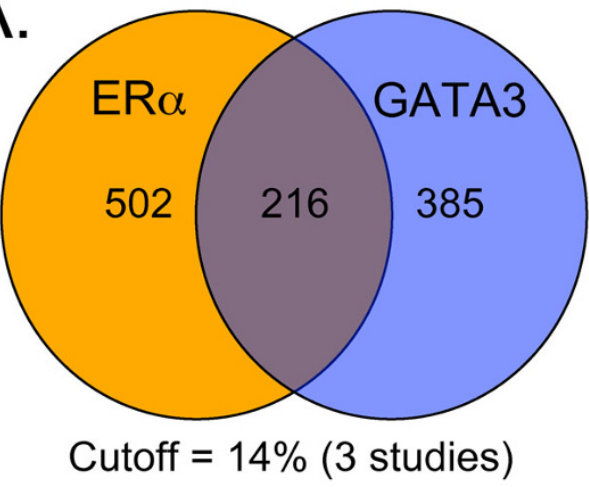

B.

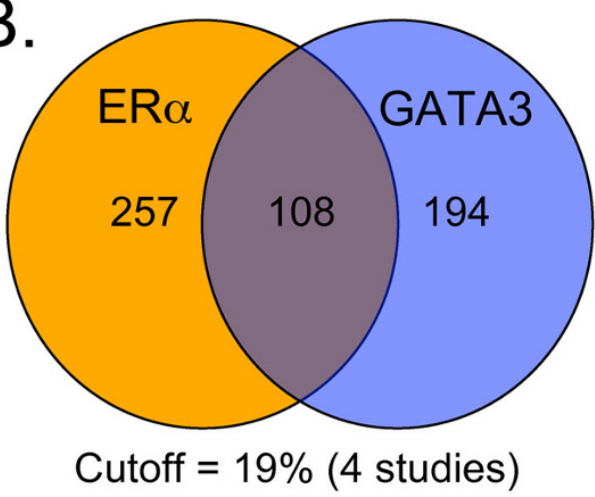

Figure I

Venn diagram showing overlap between ER $\alpha$ and GATA3 meta-analyses. (A) Overlap when the frequency cutoff is 3 studies (I4\%). (B) Overlap when the frequency cutoff is 4 studies (19\%).

(Table 2). This was reflected in a similar study comparing ER $\alpha$ over-expressed transcripts in both oligonucleotide microarray and SAGE platforms [17], where 27 genes common to the ER $\alpha$ pathway are represented here in our common ER $\alpha$ :GATA3 meta-analysis comparison [see Additional file 3]. These data not only acted as wide-ranging external validation for the individual meta-analyses, but also confirmed the extent of the involvement of GATA3 in ER $\alpha$ pathways.

Furthermore, when compared to a list of genome-wide promoters shown to be bound by ER $\alpha$ in MCF-7 cells [18] or on chromosomes 21 and 22 [19], 23 were identified in the ER $\alpha$ meta-analysis list, while 27 were identified within the GATA3 list (Table 3). This again supports both the validity of the meta-analysis technique used here, and the role of GATA3 in ER $\alpha$ pathways. It is also possible that the overlap would be even higher if the ER $\alpha$ genomic location analysis were performed on a pool of human ER $\alpha$-positive breast tumour samples as opposed to a cell-culture model
Table 2: Comparison of GATA3 and ER $\alpha$ meta-analyses, and RTPCR study

\begin{tabular}{|c|c|c|}
\hline & GATA3 Oncomine & ER $\alpha$ Oncomine \\
\hline ESRI & $\boldsymbol{V}$ & $\checkmark$ \\
\hline GATA3 & $\checkmark$ & $\checkmark$ \\
\hline TFFI & $\boldsymbol{V}$ & $\checkmark$ \\
\hline TFF3 & $\checkmark$ & $\checkmark$ \\
\hline FOXAI & $\boldsymbol{V}$ & $\checkmark$ \\
\hline XBPI & $\boldsymbol{V}$ & $\checkmark$ \\
\hline IL6ST & $\checkmark$ & $\checkmark$ \\
\hline KRTI8 & $\boldsymbol{V}$ & $\checkmark$ \\
\hline AR & $\boldsymbol{V}$ & $\checkmark$ \\
\hline BCL2 & $\boldsymbol{V}$ & $\checkmark$ \\
\hline CCNDI & $\checkmark$ & $\checkmark$ \\
\hline RERG & $\checkmark$ & $\checkmark$ \\
\hline ERBB4 & $\checkmark$ & $\checkmark$ \\
\hline NATI & $\boldsymbol{V}$ & $\checkmark$ \\
\hline SLC39A6 & $\checkmark$ & $\checkmark$ \\
\hline DNAJCI 2 & $\boldsymbol{V}$ & $\checkmark$ \\
\hline HPN & $\boldsymbol{V}$ & $\checkmark$ \\
\hline CYP2B6 & $\checkmark$ & $\checkmark$ \\
\hline CAI2 & $\checkmark$ & $\checkmark$ \\
\hline STC2 & $\boldsymbol{V}$ & $\checkmark$ \\
\hline ACADSB & $\boldsymbol{\sim}$ & $\checkmark$ \\
\hline LRBA & $\checkmark$ & $\checkmark$ \\
\hline PTPRT & $\checkmark$ & $\checkmark$ \\
\hline SULT2BI & $\boldsymbol{V}$ & $\checkmark$ \\
\hline MYB & $\boldsymbol{V}$ & $\checkmark$ \\
\hline SEMA3B & $\checkmark$ & $\checkmark$ \\
\hline RET & $\checkmark$ & $\checkmark$ \\
\hline SLC7A2 & $\checkmark$ & $\checkmark$ \\
\hline RABEPI & $\checkmark$ & \\
\hline IGFBP4 & $\checkmark$ & \\
\hline CGA & $\checkmark$ & \\
\hline GJAI & $\checkmark$ & \\
\hline PGR & & $\checkmark$ \\
\hline RARRES & & $\checkmark$ \\
\hline $\mathrm{BBC} 3$ & & $\checkmark$ \\
\hline LOC255743 & & $\checkmark$ \\
\hline
\end{tabular}

$5 \mathrm{I}$ genes were identified as being upregulated in ER $\alpha$-positive breast tumours in a recent study by Tozlu et al, and are compared with the Oncomine meta-analysis lists for ER $\alpha$ and GATA3, showing a significant overlap. $\boldsymbol{V}$ shows that this gene is represented.

system. While not to detract from the power of a model system such as MCF-7 there are likely to be a great many differences between a homogeneous cell monolayer and a 3-dimensional cancer made up of a heterogeneous cell population.

Of the 10 classifier genes previously identified in a metaanalysis of $E R \alpha$, the same 4 were identified in both metaanalyses of this study (ESR1, GATA3, FOXA1, SLC39A6) [9]. Once again this adds credence to the high-quality data obtained in our current meta-analyses.

Implicating GATA3 in control of some of these gene products is a microarray experiment performed after overex- 
Table 3: Comparison of GATA3 and ER $\alpha$ meta-analyses with previously reported binding sites (by ChIP-chip analysis)

\begin{tabular}{|c|c|}
\hline ER $\alpha$ ChIP-chip: GATA3 Oncomine & ER $\alpha$ ChIP-chip: ER $\alpha$ Oncomine \\
\hline ABCA3 & ABCA3 \\
\hline ALDH3B2 & ANXA9 \\
\hline ANXA9 & BTRC \\
\hline EPS8 & $\mathrm{C} 2$ \\
\hline ESRI & CYP5IAI \\
\hline FLJ 20152 & ESRI \\
\hline FOXAI & FLJ 13710 \\
\hline GREB | & FOXAI \\
\hline GTF2H2 & GREB I \\
\hline LOC5 1760 & KCNAB2 \\
\hline MGCI I 242 & LOC5I760 \\
\hline MGP & MB \\
\hline NAV3 & MGCII 242 \\
\hline NQOI & MSP \\
\hline PDZKI & SEMA3B \\
\hline PHFI5 & SLC27A2 \\
\hline RTNI & SLC7A2 \\
\hline SEMA3B & STARDIO \\
\hline SLC27A2 & STK39 \\
\hline SLC7A2 & TFFI \\
\hline SLC7A8 & TFF3 \\
\hline STARDIO & NRIP I \\
\hline STK39 & RUNXI \\
\hline \multicolumn{2}{|l|}{ TFF I } \\
\hline \multicolumn{2}{|l|}{ TFF3 } \\
\hline \multicolumn{2}{|l|}{ TOMM40 } \\
\hline NRIP I & \\
\hline
\end{tabular}

Oncomine meta-analysis data for GATA3 or ER $\alpha$ was compared both to a promoter list published by Laganiere et al, $(P=0.05)$, and to a chromosome array list of 30 genes identified by Carroll et al. The overlap is shown and common overlap between ER $\alpha$ and GATA3 is shown in bold.

pression of GATA3 in $293 \mathrm{~T}$ cells [20]. After expression of GATA3 elevated levels of TFF1, TFF3, KRT18, FOXA1, SLC9A3R1, TPD52, BCAS1 were observed, all of which we identified here for both GATA3 and ER $\alpha$ meta-analyses. While 293T are not breast cancer cells, it raises the question of how many more of our predicted pathway partners of GATA3 would be identified if the microarray were repeated in cells such as MCF-7 which also retain high ER $\alpha$ expression. In the example of SLC9A3R1 (NHERF1) which is a putative tumour suppressor, it was shown to increase growth of 2 breast cancer cell lines when knocked down by shRNA [21]. If GATA3 does help to control expression of NHERF1 this might be one mechanism consistent with its role in the less-aggressive differentiated luminal A breast cancers. Another example is BCAS1 (NABC1) which is overexpressed in breast carcinomas but downregulated in colorectal tumours [22,23]. Indeed, overexpression of NABC1 did not result in changes in cellcycle or anchorage-dependent growth properties in NIH3T3 cells, implying it may not be intrinsically oncogenic [24].

As GATA3 is expressed in, and regulates, luminal epithelial cells and has also been shown to regulate the MUC1 gene it is no surprise that MUC1 is also mostly expressed in luminal breast epithelial cells as well as other glandular epithelia [25]. MUC1, when abnormally expressed, leads to a loss of both cell-extracellular and cell-cell contacts. It has also been shown that MUC1 levels can be regulated by estrogen and ER $\alpha$ can bind putative binding sites derived from the MUC1 promoter in-vitro [26]. Here we reveal that both GATA3 and ER $\alpha$ coexpress with MUC1 acting as further validation of the meta-analysis technique used here. Furthermore, transfected GATA3 can activate a MUC1 promoter reporter in MCF-7 cells, even in the presence of Tamoxifen i.e. independently to ER $\alpha$ activation. This activation could be repeated in the ER $\alpha$-negative breast cancer cell line SKBR3 (Figure 2). The activation of ER $\alpha$ pathway genes was also observed with pS2 (TFF1) and KRT18 reporters (Figure 2). These data indicate that GATA3 can have its own impact on the ER $\alpha$ pathway and is not just acting indirectly via $\mathrm{ER} \alpha$.

It has also been postulated that, as the deletion of GATA3 in mammary primordia (by K14-Cre) resulted in an inability to form mammary placodes is similar to that of loss of LEF1, Msx1 and Msx2 these may all be intertwined in a transcriptional network $[4,27]$. It is of interest that in our 

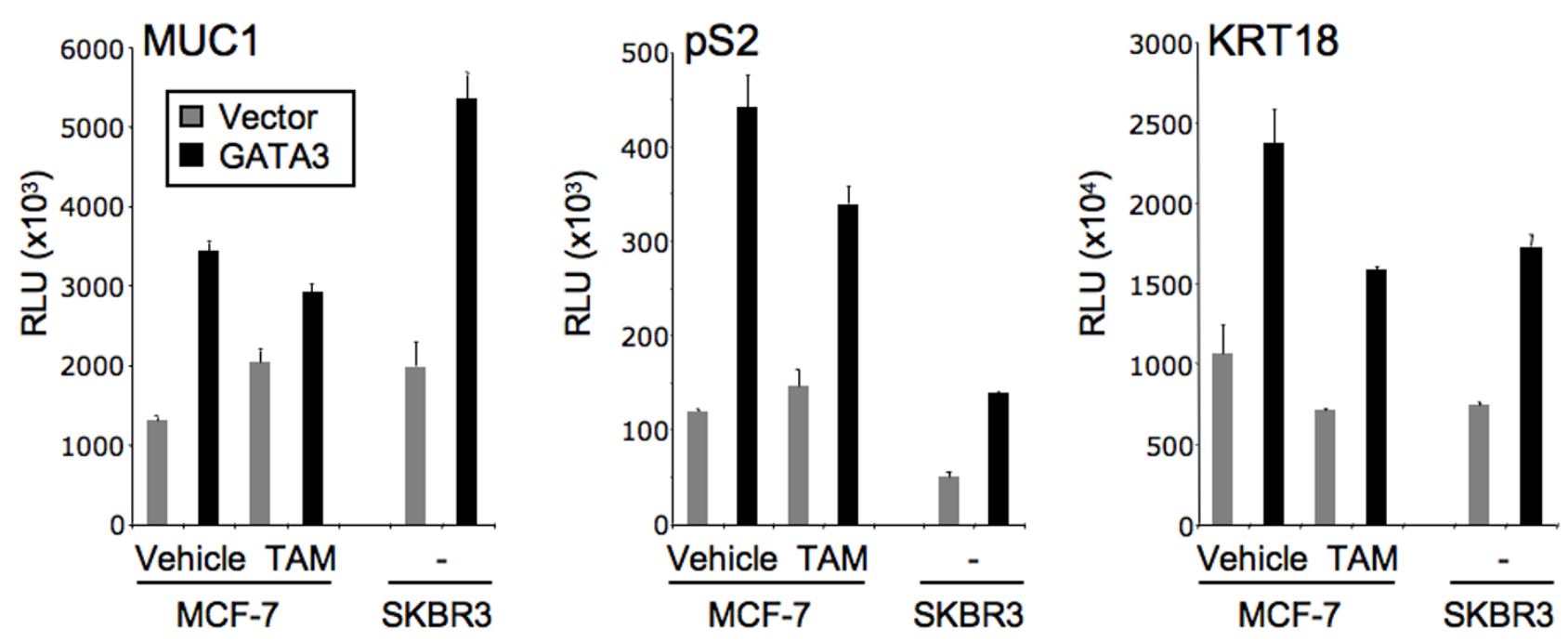

Figure 2

GATA3 can activate ER $\alpha$ pathway promoter reporters. GATA3 can activate MUCI, pS2, or keratin 18 promoter reporters, in ER $\alpha$-positive MCF-7 cells (even in the presence of tamoxifen - TAM), or in ER $\alpha$-negative SKBR3 cells.

present study we observe MSX2 coexpression both with GATA3 and ER $\alpha$, which helps to support this notion.

Using the meta-analysis data presented it is easy to build up transcriptional networks such as this and all of the data presented strongly supports (1) the quality of the metaanalysis results, (2) the concept that GATA3 is firmly entrenched within ER $\alpha$ pathways. Future in-depth analysis of the data presented may lead to novel aspects of ER $\alpha$ or GATA3 regulated pathways, and help to understand the etiology of ER $\alpha$-positive breast cancers, and management of their outcomes.

\section{Conclusion}

While GATA3 has been identified previously in a metaanalysis of ER $\alpha$ only 10 genes were identified in total [9]. Here we give an extensive list of coexpressed ER $\alpha$ genes and for the first time a reciprocal meta-analysis for GATA3 has been performed, and the results compared for overlap. This overlap was considerable, confirming the important role of GATA3 in the ER $\alpha$ pathway. The vital question raised is whether GATA3 is crucial to the ER $\alpha$ pathway only by regulation of ER $\alpha$ levels, or through further control of ER $\alpha$-regulated genes in concert with ER $\alpha$ itself. The GATA3 overexpression microarray experiment in 293T cells, and our reporter gene assays certainly implies the latter [20]. Genome-wide location analysis (ChIP-chip) of GATA3 in a well-established ER $\alpha$ system such as MCF-7 cells, as well as specific analysis of the ER $\alpha$ pathway in GATA3 conditional knockout mice will yield vital information regarding the extent that GATA3 is integral to the ER $\alpha$ pathway.

\section{Authors' contributions}

BW conceived and designed the study, performed the meta-analyses, the reporter assays, and wrote the manuscript. VG critically reviewed the manuscript, and approved the final version.

\section{Additional material}

\section{Additional file 1}

GATA3 Oncomine meta-analysis. Meta-analysis results from 21 Oncomine studies shown. Coexpressing genes with GATA3 are shown with a cutoff of 3 studies (14\% of the 21 studies).

Click here for file

[http://www.biomedcentral.com/content/supplementary/14764598-7-49-S1.xls]

\section{Additional file 2}

ER $\alpha$ Oncomine meta-analysis. Meta-analysis results from 21 Oncomine studies shown. Coexpressing genes with ER $\alpha$ are shown with a cutoff of 3 studies (14\% of the 21 studies).

Click here for file

[http://www.biomedcentral.com/content/supplementary/14764598-7-49-S2.xls]

\section{Additional file 3}

External data comparison. Comparison of data to that of Abba et al, 2005. ER $\alpha$ pathway genes common to oligo microarrays, SAGE and our meta-analysis overlap.

Click here for file

[http://www.biomedcentral.com/content/supplementary/14764598-7-49-S3.xls] 


\section{Acknowledgements}

We thank John Coligan, NIH, for pcDNA3-GATA3. Funding was provided by the Canadian Institute for Cancer Research (VG) and a McGill University Health Centre fellowship (BW).

\section{References}

I. Ho IC, Pai SY: GATA-3 - not just for Th2 cells anymore. Cell Mol Immunol 2007, 4:15-29.

2. Inman D, Kawana K, Schust D, Lininger R, Young S: Cyclic regulation of T-Bet and GATA-3 in human endometrium. Reprod Sci 2008, I 5:83-90.

3. Mehra R, Varambally S, Ding L, Shen R, Sabel MS, Ghosh D, Chinnaiyan AM, Kleer CG: Identification of GATA3 as a breast cancer prognostic marker by global gene expression meta-analysis. Cancer Res 2005, 65: I I259-I I 264.

4. Asselin-Labat ML, Sutherland KD, Barker H, Thomas R, Shackleton M, Forrest NC, Hartley L, Robb L, Grosveld FG, Wees I van der, Lindeman GJ, Visvader JE: Gata-3 is an essential regulator of mammary-gland morphogenesis and luminal-cell differentiation. Nat Cell Biol 2007, 9:20I-209.

5. Kouros-Mehr H, Slorach EM, Sternlicht MD, Werb Z: GATA-3 maintains the differentiation of the luminal cell fate in the mammary gland. Cell 2006, 1 27: I04I-1055.

6. Garcia-Closas M, Troester MA, Qi Y, Langerod A, Yeager M, Lissowska J, Brinton L, Welch R, Peplonska B, Gerhard DS, Gram IT, Kristensen V, Borresen-Dale AL, Chanock S, Perou CM: Common genetic variation in GATA-binding protein 3 and differential susceptibility to breast cancer by estrogen receptor alpha tumor status. Cancer Epidemiol Biomarkers Prev 2007, 16:2269-2275.

7. van 't Veer LJ, Dai $H$, Vijver MJ van de, He YD, Hart AA, Mao M, Peterse HL, Kooy K van der, Marton MJ, Witteveen AT, Schreiber G], Kerkhoven RM, Roberts C, Linsley PS, Bernards R, Friend SH: Gene expression profiling predicts clinical outcome of breast cancer. Nature 2002, 415:530-536.

8. Eeckhoute J, Keeton EK, Lupien M, Krum SA, Carroll JS, Brown M: Positive cross-regulatory loop ties GATA-3 to estrogen receptor alpha expression in breast cancer. Cancer Res 2007, 67:6477-6483.

9. Schneider J, Ruschhaupt M, Buness A, Asslaber M, Regitnig P, Zatloukal K, Schippinger W, Ploner F, Poustka A, Sultmann H: Identification and meta-analysis of a small gene expression signature for the diagnosis of estrogen receptor status in invasive ductal breast cancer. Int / Cancer 2006, I I 9:2974-2979.

10. Oh DS, Troester MA, Usary J, Hu Z, He X, Fan C, Wu J, Carey LA, Perou CM: Estrogen-regulated genes predict survival in hormone receptor-positive breast cancers. J Clin Oncol 2006, 24:1656-1664

II. Kouros-Mehr H, Bechis SK, Slorach EM, Littlepage LE, Egeblad M, Ewald AJ, Pai SY, Ho IC, Werb Z: GATA-3 links tumor differentiation and dissemination in a luminal breast cancer model. Cancer Cell 2008, 13:141-152.

12. Wilson BJ, Giguere V: Identification of novel pathway partners of p68 and p72 RNA helicases through Oncomine meta-analysis. BMC Genomics 2007, 8:419.

13. Oncomine [http://www.oncomine.org]

14. Genecards [http://www.genecards.org]

15. Barry JB, Laganiere J, Giguere V: A single nucleotide in an estrogen-related receptor alpha site can dictate mode of binding and peroxisome proliferator-activated receptor gamma coactivator I alpha activation of target promoters. Mol Endocrinol 2006, 20:302-310.

16. Tozlu S, Girault I, Vacher S, Vendrell J, Andrieu C, Spyratos F, Cohen $P$, Lidereau R, Bieche I: Identification of novel genes that cocluster with estrogen receptor alpha in breast tumor biopsy specimens, using a large-scale real-time reverse transcription-PCR approach. Endocr Relat Cancer 2006, I 3: I I09-I I 20.

17. Abba MC, Hu Y, Sun H, Drake JA, Gaddis S, Baggerly K, Sahin A, Aldaz $\mathrm{CM}$ : Gene expression signature of estrogen receptor alpha status in breast cancer. BMC Genomics 2005, 6:37.

18. Laganiere J, Deblois G, Lefebvre C, Bataille AR, Robert F, Giguere V: From the Cover: Location analysis of estrogen receptor alpha target promoters reveals that FOXAI defines a domain of the estrogen response. Proc Natl Acad Sci USA 2005, 102: ||65I-1|656.
19. Carroll JS, Liu XS, Brodsky AS, Li W, Meyer CA, Szary AJ, Eeckhoute J, Shao W, Hestermann EV, Geistlinger TR, Fox EA, Silver PA, Brown $M$ : Chromosome-wide mapping of estrogen receptor binding reveals long-range regulation requiring the forkhead protein FoxAI. Cell 2005, I 22:33-43.

20. Usary J, Llaca V, Karaca G, Presswala S, Karaca M, He X, Langerod A, Karesen R, Oh DS, Dressler LG, Lonning PE, Strausberg RL, Chanock S, Borresen-Dale AL, Perou CM: Mutation of GATA3 in human breast tumors. Oncogene 2004, 23:7669-7678.

2I. Pan Y, Wang L, Dai JL: Suppression of breast cancer cell growth by $\mathrm{Na}+/ \mathrm{H}+$ exchanger regulatory factor I (NHERFI). Breast Cancer Res 2006, 8:R63.

22. Collins C, Rommens JM, Kowbel D, Godfrey T, Tanner M, Hwang SI, Polikoff D, Nonet G, Cochran J, Myambo K, Jay KE, Froula J, Cloutier T, Kuo WL, Yaswen P, Dairkee S, Giovanola J, Hutchinson GB, Isola J, Kallioniemi OP, Palazzolo M, Martin C, Ericsson C, Pinkel D, Albertson D, Li WB, Gray JW: Positional cloning of ZNF217 and NABCI: genes amplified at 20q13.2 and overexpressed in breast carcinoma. Proc Natl Acad Sci USA 1998, 95:8703-8708.

23. Correa RG, de Carvalho AF, Pinheiro NA, Simpson AJ, de Souza SJ: NABCI (BCASI): alternative splicing and downregulation in colorectal tumors. Genomics 2000, 65:299-302.

24. Beardsley DI, Kowbel D, Lataxes TA, Mannino JM, Xin H, Kim WJ, Collins C, Brown KD: Characterization of the novel amplified in breast cancer-I (NABCI) gene product. Exp Cell Res 2003, 290:402-4I3.

25. Abba MC, Nunez MI, Colussi AG, Croce MV, Segal-Eiras A, Aldaz CM: GATA3 protein as a MUCI transcriptional regulator in breast cancer cells. Breast Cancer Res 2006, 8:R64.

26. Zaretsky JZ, Barnea I, Aylon Y, Gorivodsky M, Wreschner DH, Keydar I: MUCI gene overexpressed in breast cancer: structure and transcriptional activity of the MUCI promoter and role of estrogen receptor alpha (ERalpha) in regulation of the MUCI gene expression. Mol Cancer 2006, 5:57.

27. Naylor MJ, Ormandy CJ: Gata-3 and mammary cell fate. Breast Cancer Res 2007, 9:302.

Publish with Bio Med Central and every scientist can read your work free of charge

"BioMed Central will be the most significant development for disseminating the results of biomedical research in our lifetime."

Sir Paul Nurse, Cancer Research UK

Your research papers will be:

- available free of charge to the entire biomedical community

- peer reviewed and published immediately upon acceptance

- cited in PubMed and archived on PubMed Central

- yours - you keep the copyright 